\title{
Spawanie blach dla przemysłu motoryzacyjnego metodą MAG ze zmienną biegunowością (AC Pulse)
}

\author{
Welding of automotive steels using MAG method \\ with variable polarity (AC Pulse)
}

\section{Streszczenie}

W artykule przedstawiono analizę warunków technologicznych spawania materiałów konstrukcyjnych nową, innowacyjną metodą. Omówiono badania technologiczne wariantu spawania AC MIG PULSE, opracowanego przez japońską firmę OTC Daihen i określono właściwości uzyskanych połączeń oraz ich zastosowanie do łączenia cienkich blach stalowych z nowoczesnymi powłokami w przemyśle samochodowym.
Abstract

The analysis of technological conditions of welding of zinc-coated plate using modern, innovative technique has been presented. Technological investigation of AC MIG PULSE welding technique, developed by Japanese company OTC Daihen has been carried out (MAG welding using variable polarity). The properties of welded joints has been presented and possibilities of application of this method in automotive industry has also been discussed.

\section{Wstęp}

Opracowanie nowych rozwiązań w zakresie zaawansowanych układów sterowania urządzeń spawalniczych umożliwiło wprowadzenie wariantów spawania MIG/MAG, które odpowiadają na zapotrzebowanie przemysłu samochodowego. Zastosowanie metod niskoenergetycznych, takich jak CMT lub ColdArc, umożliwia zmniejszenie odkształceń spawanych elementów stalowych, ograniczenie rozprysku oraz znaczną poprawę estetyki złącza. Najnowszym osiągnięciem w zakresie niskoenergetycznych metod spawania elektrodą topliwą jest zastosowanie prądu pulsującego o zmiennej biegunowości.

Dr inż. Tomasz Pfeifer, mgr inż. Agnieszka Kiszka - Instytut Spawalnictwa, Gliwice.

\section{Materiały i urządzenia zastosowane do badań}

Badania technologiczne procesu spawania prądem ze zmienną biegunowością wykonano na stanowisku zmechanizowanym. Do badań technologicznych zastosowano urządzenie DW 300 firmy OTC Daihen (rys. 1). Wykorzystano drut elektrodowy PN-EN ISO 14341-AG3Si1 o średnicy 1,0 i 1,2 mm. Gaz osłonowy stanowiła mieszanka PN-EN ISO 14175 -M21-ArC-18. Podczas prób stosowano natężenie przepływu gazu osłonowego wynoszące $12 \mathrm{l} / \mathrm{min}$.

Prace obejmowały przeprowadzenie prób technologicznych spawania złączy zakładkowych, doczołowych i teowych z różnorodnych stali z powłokami cynkowymi i cynkowo-żelaznymi o grubości $2,5 \div 12 \mu \mathrm{m}$, nanoszonymi zarówno w sposób zanurzeniowy, jak i galwaniczny, powszechnie stosowanymi w przemyśle samochodowym [1]. Do badań zastosowano 


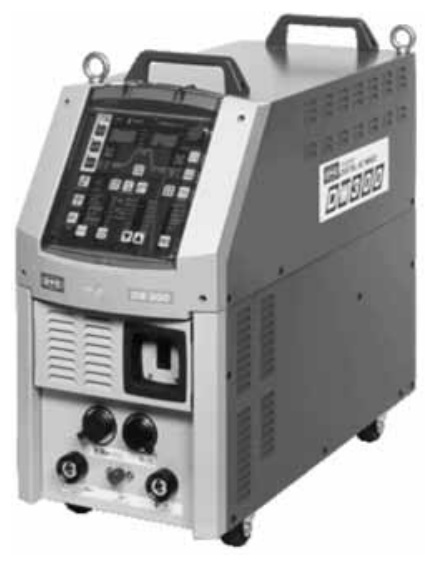

Rys. 1. Urządzenie do spawania DW 300 firmy OTC Daihen Fig. 1. Welding device DW 300 OTC Daihen

następujące stale: HX 420 LAD Z 100 MBO, H340 LAD ZF 100 RBO, HX 260 LAD Z140 MBO, CPW 800 Z100 MBO, HC 220Y+ZE50/50 AO, DX53D ZF 100 RBO, DX52D Z100 MBO, DC04+ZE 25/25 AO, HCT600X ZF100 RBO [3, 4].

\section{Wyniki badań}

W pierwszym etapie badań zarejestrowano przebiegi czasowe natężenia prądu i napięcia łuku w czasie spawania (rys. 2). Do tego celu zastosowano nowopracowany w Instytucie Spawalnictwa, w ramach pracy badawczej, system monitorowania parametrów elektrycznych procesu spawania [2].

$Z$ rysunku 2 wynika, że natężenie prądu i napięcie łuku zmieniają swoją biegunowość podczas spawania. Badania technologiczne wykazały, że istnieje możliwość regulacji udziału składowej zmiennej w przebiegu prądu spawania (regulacja tzw. parametru EN Ratio), a zarazem wpływania na przebieg procesu i właściwości złączy.

Podczas spawania oceniano stabilność procesu, a wykonane złącza poddawano badaniom wizualnym. Jako kryterium poprawności wyboru parametrów i warunków spawania zastosowano poziom jakości B ( $z$ wyjątkiem wysokości nadlewu lica i wycieku w grani, dla których przyjęto poziom jakości C) wg PN-EN

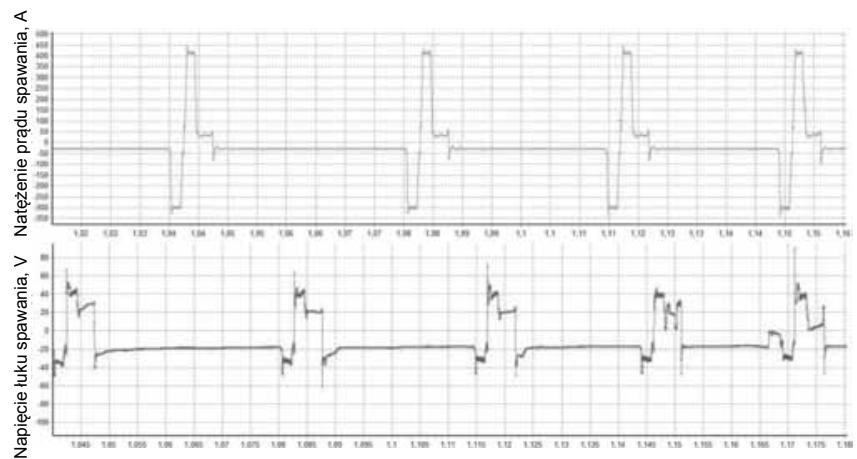

Rys. 2. Przebieg zmian napięcia i natężenia prądu podczas spawania blachy z powłoką cynkowa

Fig. 2. Current and voltage chart during welding of zinc coated steel
ISO 5817. Kolejnym kryterium było jak najmniejsze uszkodzenie warstwy cynku. Zbadano także wpływ udziału składowej ujemnej w przebiegu prądu spawania na proces spawania i jakość połączeń. Stwierdzono, że przy najmniejszym udziale składowej ujemnej głębokość wtopienia i stopień uszkodzenia warstwy ochronnej są najmniejsze. Na rysunkach $3 \div 5$ przedstawiono wybrane połączenia od strony lica i grani oraz ich makrostrukturę.

a)

b)

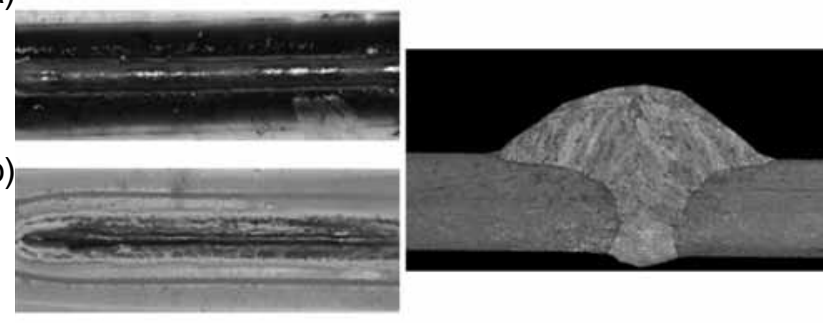

Rys. 3. Widok oraz makrostruktura złącza doczołowego wykonanego na I ze stali HX 420 LAD Z 100 MBO grubości 3 mm; A - widok od strony lica spoiny, B - widok od strony grani. Trawienie oddczynnnikeim Adlera, powiększenie 5,5x

Fig. 3. View and macrostructure of $3 \mathrm{~mm}$ thick HX 420 LAD Z 100 MBO butt weld, A - view of the weld face, B - view of the weld root, etching by Adler, magn. 5,5x

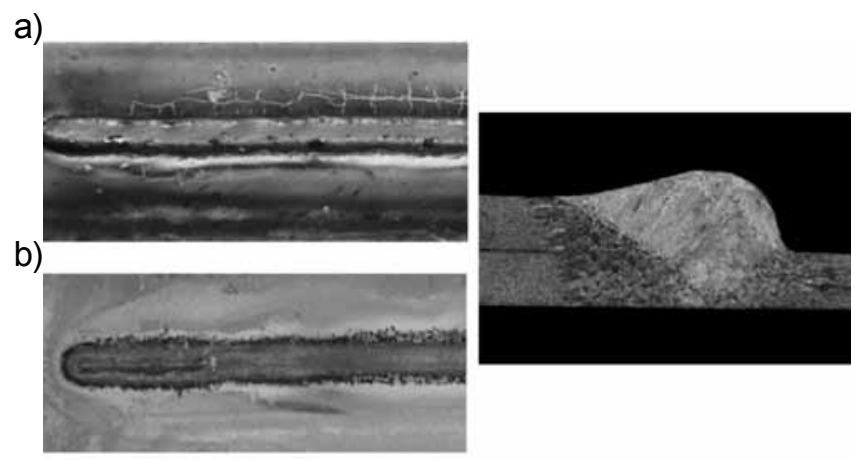

Rys. 4. Widok oraz makrostruktura złącza zakładkowego ze stali HX 260 LAD Z140 MBO grubości 0,8 mm; A - widok od strony lica spoiny, B - widok od strony grani. Trawienie odczynikiem Adlera, powiększenie $12,5 x$

Fig. 4. View and macrostructure of $0,8 \mathrm{~mm}$ thick HX 260 LAD Z 140 MBO butt weld, A - view of the weld face, B - view of the weld root, etching by Adler, magn. $12,5 \mathrm{x}$
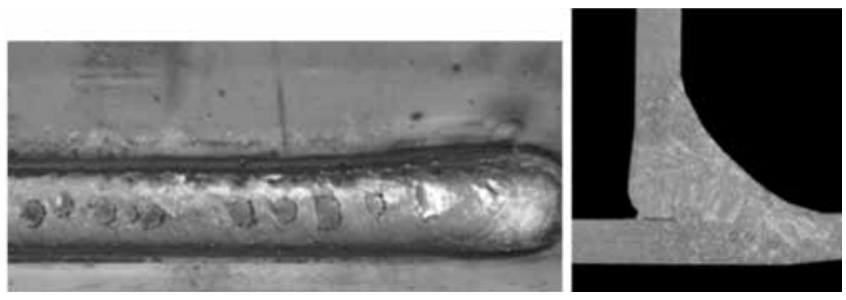

Rys. 5. Widok oraz makrostruktura złącza teowego ze stali HCT600X ZF 100 RBO grubości 2 mm; widok od strony lica. Trawienie odczynnikiem Adlera, powiększenie 3,5x

Fig. 5. View and macrostructure of $2 \mathrm{~mm}$ thick HCT600X ZF 100 RBO T-joint, view of the weld face, etching by Adler, magn. 3,5x 


\section{Podsumowanie}

Badania technologiczne, wizualne oraz metalograficzne makroskopowe wykazały, że proces spawania elektrodą topliwą ze zmienną biegunowością prądu i napięcia, realizowany za pomocą urządzenia DW 300 firmy OTC Daihen, może być stosowany do spawania cienkich blach stalowych niestopowych i niskostopowych z powłokami cynkowymi i cynkowożelaznymi nanoszonymi zarówno w sposób zanurzeniowy, jak i galwaniczny. Proces spawania przebiega mniej stabilnie niż tradycyjne spawanie metodą MAG i jest głośniejszy. Złącza spawane charakteryzują się dobrą jakością i estetyką oraz są wolne od rozprysku. Uszkodzenie warstwy cynku jest również nieznaczne. Urządzenie oferuje dość szerokie możliwości - oprócz podstawowych parametrów spawania zapewnia również możliwość regulowania ilości wprowadzonego ciepła i napięcia łuku dzięki zmianom udziału składowej ujemnej w przebiegu prądu spawania, umożliwiając wykonywanie złączy spawanych doczołowych, zakładkowych i teowych blach o grubościach od $0,8 \mathrm{~mm}$ z różnymi powłokami ochronnymi. Należy jednak pamiętać o tym, że im mniejsza grubość blachy, tym węższe są przedziały poszczególnych parametrów spawania zapewniających uzyskanie dobrej jakości i estetyki. Spawać można również elementy o większej grubości $(3,4 \mathrm{~mm})$, ale wtedy proces pod względem ilości wprowadzonego ciepła jest podobny do tradycyjnego spawania metodą MAG. Badania wykazały, że na przebieg procesu łączenia nie wpływa gatunek spawanego materiału, lecz jedynie jego grubość i rodzaj powłoki. Obserwacje procesu spawania i badania wizualne wykazały, że najtrudniej spawa się elementy zabezpieczone powłoką cynkową Z140 (grubość powłoki $7 \div 12 \mu \mathrm{m}$ ), a najłatwiej zabezpieczone powłoką cynkową o grubości $5 \div 12 \mu \mathrm{m}$, zawierającą domieszkę ok. $10 \% \mathrm{Fe}$, typu ZF 100. Wynika z tego, że im większa grubość i gęstość powłoki cynkowej, tym gorsze warunki spawania, a uszkodzenie warstwy cynku większe. Trudniej dobrać jest parametry spawania, a przedziały parametrów zapewniających uzyskanie połączeń o dobrej jakości i estetyce stają się bardzo wąskie. Wprowadzenie do powłoki cynkowej dodatku żelaza znacznie poprawia przebieg procesu, jego stabilność oraz jakość uzyskanych połączeń.

\section{Literatura}

[1] Matusiak J., Pfeifer T., Wyciślik J. , Kiszka A.: Analiza wpływu warunków technologicznych innowacyjnych technik spajania różnych materiałów konstrukcyjnych z nowoczesnymi powłokami ochronnymi na stan środowiska pracy. Praca badawcza Instytutu Spawalnictwa nr Ma-34, Gliwice 2011.

[2] Szubert L., Skoczewski P, Welcel M.: System rejestracji parametrów elektrycznych procesu spawania dla wielu stanowisk produkcyjnych. Praca badawcza Instytutu Spawalnictwa nr Fc-89, Gliwice 2010.
[3] PN-EN 10346 Wyroby płaskie stalowe powlekane ogniowo w sposób ciągły. Warunki techniczne dostawy.

[4] PN-EN 10152 Wyroby płaskie stalowe walcowane na zimno ocynkowane elektrolitycznie do obróbki plastycznej na zimno. Warunki techniczne dostawy.

\section{W następnym numerze}

\section{Tomasz Urbański}

Węzeł hybrydowy - prognozowanie odkształceń spawalniczych panelu I-core na podstawie planowanie eksperymentu dwuwartościowego

Marian Gwóźdź, Tomasz Michałowski

Elementy niezawodności stalowych spawanych zbiorników na ciecze i gazy płynne

\section{Elżbieta Jankowska}

Spawanie stali - narażenie na cząstki zawarte w dymach spawalniczych

\section{Mirosław Łomozik, Adam Pilarczyk}

TPF wer. 3,0 do tworzenia wykresów przemian fazowych austenitu w stalach w warunkach Spawalniczych CTPc-S

\section{Bernard Wichtowski, Marek Wichtowski}

Normowe wymagania wykonawcze i spawalnicze w konstrukcjach budowlanych i jakość spoin w badaniach NDT 